\title{
Anthropometrics of University Students in Northern Mexico
}

\section{Juan Luis Hernandez-Arellano1, Giselle Talavera-Aguirre1, J. Nieves Serratos-Perez ${ }^{2}$, Aide Aracely Maldonado-Macias ${ }^{3}$, Jorge Luis Garcia-Alcaraz ${ }^{3}$}

${ }^{1}$ Department of Design, Autonomous University of Ciudad Juarez, Ciudad Juarez, Mexico

${ }^{2}$ Department of Work Sciences, University of Guanajuato, Leon, Mexico

${ }^{3}$ Department of Industrial Engineering and Systems, Autonomous University of Ciudad Juarez, Ciudad Juarez, Mexico

Email:luis.hernandez@uacj.mx

How to cite this paper: HernandezArellano, J.L., Talavera-Aguirre, G., SerratosPerez, J.N., Maldonado-Macias, A.A. and Garcia-Alcaraz, J.L. (2016) Anthropometrics of University Students in Northern Mexico. Open Journal of Safety Science and Technology, 6, 143-155.

http://dx.doi.org/10.4236/ojsst.2016.64011

Received: November 15, 2016

Accepted: December 16, 2016

Published: December 19, 2016

Copyright $\odot 2016$ by authors and Scientific Research Publishing Inc. This work is licensed under the Creative Commons Attribution International License (CC BY 4.0).

http://creativecommons.org/licenses/by/4.0/

\begin{abstract}
The main objective of this research was to build a database on anthropometric features from a sample of students enrolled in the Industrial Design program at the Universidad Autonoma de Ciudad Juarez (UACJ), to contrast anthropometric data with other Mexican regions, and to generate predictive models of the participants' body dimensions. A set of 36 body dimensions were measured based on international standards. Two anthropometric kits Rosscraft model Centurion were used for measurements. 140 students, 70 male and 70 female, enrolled in the Industrial Design program at the UACJ were measured. The values of mean, standard deviation, and percentiles were calculated. Besides, 26 predictive models of body segments were developed using simple linear regression. Body weight and stature of students in Northern Mexico are significant larger than people from other Mexican regions. We now hold anthropometric data of 36 body dimensions and 26 predictive models of body segments.
\end{abstract}

\section{Keywords}

Anthropometry, Product Design, Statistics and Data Analysis, Industrial Design

\section{Introduction}

Physical features of human beings are in constant evolution. In countries like Mexico, recent improvements in feeding patterns and health care have had an important impact on the bodily dimensions of their populations. This leads to the need for anthropometric data to be constantly updated. Anthropometric data is applied mainly in the design of objects, products and spaces to be used and/or inhabited by the subjects who were 
measured. Some examples are school/academic, home and urban furniture, housewares, tools, cars, workstations, among others. Some studies have shown that school furniture used in primary schools do not match the body size of students, thus favoring musculoskeletal discomfort in children [1]. Updated anthropometric data is very important for any population/civilization since the determination of the correct dimensions of objects depends largely on upgrading existing anthropometric data.

In Mexico, there are few studies focused on generating anthropometric data of the population. Probably, one of the first research study related to anthropometry in Mexico was published in 1933, and it included a historical collection of physical anthropology and anthropometry [2]. Another study reported anthropometric data of students and workers of the Universidad Nacional Autónoma de México (UNAM) and other Mexican cities [3]. The book "The anthropometric technique applied to industrial design", in which the main anthropometric procedures and their applications of the product design are mentioned [4]. Ergonomists' Society of Mexico [5] published on its website (www.semac.org) the results from what is called a national anthropometric study.

A comprehensive search starting on the year 2000, yielded the following studies related to anthropometry research in Mexico: 1) The book "Anthropometric dimensions of Latin American Populations: Mexico, Cuba, Colombia, Chile” which includes anthropometric data gathered from samples in four Mexican locations (Guadalajara, Leon, Mexico-USA border, and Mexico City) as well as samples from the other mentioned countries [6]; 2) Anthropometric study of primary school students in the western region of Mexico [7]; 3) Anthropometric data of people suffering from crucial paraplegia in the Mexican states of Sonora and Sinaloa [8];4) Anthropometric dimensions of workers (male and female) of Ciudad Juarez [9]. Anthropometric data of automotive industry workers in northwestern Mexico [10]; 5) Anthropometric measurements for hand-tools design [11].

Also, in Mexico anthropometric studies focused on specific populations have been developed for seniors [6] [12], athletes [13], and people with dwarfism [14].

One of the applications given to the anthropometric data is the generation of predictive models of body segments [15]. These models help when anthropometric data to determine the dimensions of an object/product are not enough. In this context, www.ergonautas.com website contains an application that allows estimating the length of seven body segments in relation to stature. This application was developed using a anthropometric data developed in 1966 [15]. In the same way, predictive models of 11 body segments of Mexican children from 6 to 12 years old were developed [7].

This article addresses the case of the Universidad Autonoma de Ciudad Juárez (UACJ). Here, students enrolled in the Industrial Design program develop prototypes, models, and designs used by them in different tests, such as functionality, usability, and product validation. Due to the lack of anthropometric data on the population in northern Mexico, the designs are developed using information coming from other populations, the most common being from the United States of America [16] or from the western region of Mexico [6]. This leads to unsuitable designs for the anthropometric characte- 
ristics of the students who would be the primary users of those developments. As an undesirable and unfair result, the design students get failed in the mentioned procedures.

This research had three objectives. The first objective was to build a database on anthropometric features from a sample of students enrolled in the Industrial Design program at the UACJ. The second objective was to compare the body weight and stature with data from other Mexican regions. The final objective was to generate predictive models of the participants' body dimensions, based on their stature.

\section{Materials and Methods}

\subsection{Participants}

The sample was composed of students enrolled in the Industrial Design program at the UACJ. The inclusion criteria were:

- Being a student at any level of the industrial design program

- Being free of physical injuries at the time of measurements

- Not having sustained a single bone fracture throughout their entire life

Ethics committee of the Universidad Autonoma de Ciudad Juarez, Mexico reviewed and approved the study. Participants signed a consent form accepting their participation in the study. Also, participants were informed of the wearing requirements, objectives, benefits of the study, as well as the absence of health risks by participating on it. They were informed that the data gathered would be treated in full confidentially and used for academic purposes only.

\subsection{Materials}

Two anthropometric kits Rosscraft model Centurion with an accuracy of $0.5 \mathrm{~mm}$ were used for measurements. The anthropometric kit has a precision and calibration certificate issued by the manufacturer. The perimeter of the head, arms and legs were measured using a flat steel tape included in the anthropometric kit. The weight was recorded using a Torino scale that was constantly adjusted during the course of the study. In addition to the measurements, participants were asked to fill out a survey enquiring on demographic data.

\subsection{Variables}

Thirty-six body dimensions were measured. The site and definition of each anthropometric parameter were based on the standard procedure [17]. Table 1 shows the names of the dimensions.

\subsection{Study Organization}

A team of two students and two researchers (called anthropometrist) were trained to perform anthropometric measurements and their procedures were analyzed to corroborate consistency in measurements. All measurements were performed in the Ergonomic Product Design Lab at the UACJ. All measurements were taken in the afternoon, 
Table 1. Anthropometric dimensions measured in the study.

\begin{tabular}{cccc}
\hline $\mathrm{N}^{\circ}$ & Body dimension & $\mathrm{N}^{\circ}$ & Body dimension \\
\hline 1 & Body weight & 19 & Shoulder-elbow length, sitting \\
2 & Stature, standing & 20 & Elbow-finger tips length, sitting \\
3 & Eye height, standing & 21 & Thorax depth, sitting \\
4 & Shoulder height, standing & 22 & Abdominal depth, sitting \\
5 & Elbow height, standing & 23 & Head breadth, sitting \\
6 & Hip height, standing & 24 & Biacromial shoulder breadth, sitting \\
7 & Knuckle height, standing & 25 & Bideltoid shoulder breadth, sitting \\
8 & Finger tips height, standing & 26 & Hip breadth, sitting \\
9 & Height, sitting & 27 & Arm reach to wall, lateral, standing \\
10 & Eye height, sitting & 28 & Shoulder-fist length, standing \\
11 & Shoulder height, sitting & 29 & Maximum horizontal reach, standing \\
12 & Thigh height, sitting & 30 & Maximum vertical reach, standing \\
13 & Knee height, sitting & 31 & Maximum Arms Span, standing \\
14 & Popliteal height, sitting & 32 & Elbow-to-elbow breadth, standing \\
15 & Thigh thickness, sitting & 33 & Hand length \\
16 & Buttock-knee length, sitting & 34 & Hand breadth \\
17 & Buttock-popliteal cavity length, sitting & 35 & Foot length, standing \\
18 & Head length, sitting & 36 & Foot breadth, standing \\
\hline
\end{tabular}

and the subjects were barefooted and wore T-shirt and thin shorts. In addition to the measurements, participants completed a form with demographic information (age, gender, date of measurement, and place of birth) and signed a consent form. The measurements were performed in four posts.

The four post were organized according with the body dimensions and the measurement instrument. The first post included the standing heights; the second post included the diameters, deeps, and reaches; the third post included the sitting measurements; and the fourth post included the face, head, feet, and hands measurements. In every post, an anthropometrist performed the measurements, and a second anthropometrist wrote the measurements in a data sheet previously designed. Additionally, the second anthropometrist guided the participants inside the measurement room, gave the instructions about the proper clothing, and placed de participants in the correct positions. In order to avoid fatigue effects, a rotation schedule was designed every $30 \mathrm{mi}-$ nutes.

The distribution of the body dimensions were organized as follows (see Table 1 to identify the body dimensions):

Post 1: Body weight, body dimensions $2-8$

Post 2: body dimensions 9 - 26

Post 3: body dimensions $27-34$

Post 4: body dimensions $35-36$ 
Participants were cited one week in advance and notified about the proper clothing needed in the study. If women brought hairpins, they were removed so they would not interfere with the measurement. All subjects were also asked to empty their pockets and other personal items such as watches, bracelets, etc.

The procedure was performed in approximately 15 minutes. The coordinator of the research team supervised the whole procedure, and with the help of a research assistant checked every data sheet at the end of the measurement of each subject. Finally, when the measurement process was finished, the anthropometer and other measurement devices were cleaned and cheeked to verify their accuracy.

\subsection{Statistics}

Because the population was known and finite (450 students of the Industrial Design program), the sample size was determined using the Equation (1).

$$
n=\frac{N * Z^{2} * p * q}{d^{2} *(N-1)+Z * p * q}
$$

where:

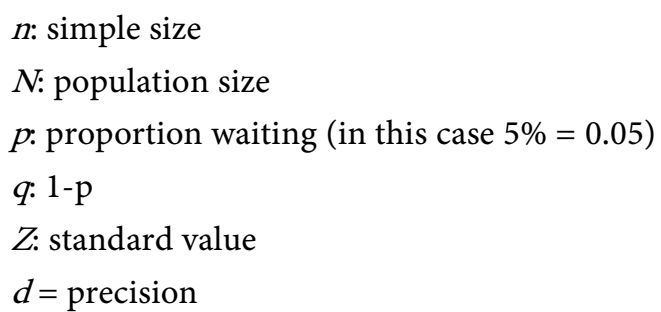

Data were captured in Excel $^{\circledR}$ software and later migrated for statistical analysis in SPSSv17 software. Prior to any statistical analysis, search and treatment of outliers considering the acceptable ranges for each dimension was performed. Arithmetic mean, standard deviation, minimum, and maximum were calculated. The differences between anthropometric data collected in this study and those from other populations were calculated using one side T-test. For the development of predictive models of body segments, the simple linear regression analysis was applied. A value of $\alpha=0.05$ was used in all calculations.

\section{Results}

A convenience sample of 140 students was drawn from the population and chosen randomly. The participation was on a voluntary basis. We selected 70 men and 70 women with average age of $21.5( \pm 1.5)$ and $21.2( \pm 2.3)$, respectively. The study was completed in six months starting on July 2014 and ending on December 2014.

\subsection{Anthropometric Data}

The results obtained after performing anthropometric measurements (mean, standard deviation, minimum, maximum for male and female students are shown in Table 2 and Table 3, respectively. 
Table 2. Anthropometric data of male students.

\begin{tabular}{|c|c|c|c|c|c|}
\hline \multirow{2}{*}{$\mathrm{N}^{\circ}$} & \multirow{2}{*}{ Body dimension } & \multicolumn{4}{|c|}{ Male $(\mathrm{N}=70)$} \\
\hline & & Mean & S.D. & Min & Max \\
\hline 1 & Body weight & 80 & 19 & 51 & 163 \\
\hline 2 & Stature, standing & 1726 & 72 & 1560 & 1859 \\
\hline 3 & Eye height, standing & 1617 & 63 & 1472 & 1726 \\
\hline 4 & Shoulder height, standing & 1426 & 66 & 1270 & 1552 \\
\hline 5 & Elbow height, standing & 1099 & 64 & 975 & 1404 \\
\hline 6 & Hip height, standing & 995 & 62 & 835 & 1223 \\
\hline 7 & Knuckle height, standing & 759 & 42 & 654 & 876 \\
\hline 8 & Finger tips height, standing & 662 & 39 & 555 & 757 \\
\hline 9 & Height, sitting & 1308 & 50 & 1166 & 1446 \\
\hline 10 & Eye height, sitting & 1211 & 45 & 1090 & 1328 \\
\hline 11 & Shoulder height, sitting & 1008 & 41 & 898 & 1120 \\
\hline 12 & Thigh height, sitting & 577 & 31 & 501 & 646 \\
\hline 13 & Knee height, sitting & 522 & 33 & 445 & 600 \\
\hline 14 & Popliteal height, sitting & 423 & 28 & 342 & 501 \\
\hline 15 & Thigh thickness, sitting & 142 & 20 & 107 & 209 \\
\hline 16 & Buttock-knee length, sitting & 602 & 34 & 507 & 678 \\
\hline 17 & Buttock-popliteal length, sitting & 479 & 36 & 390 & 552 \\
\hline 18 & Head length, sitting & 199 & 7 & 183 & 214 \\
\hline 19 & Shoulder-elbow length, sitting & 349 & 26 & 295 & 392 \\
\hline 20 & Elbow-finger tips length, sitting & 478 & 24 & 417 & 519 \\
\hline 21 & Thorax depth, sitting & 212 & 26 & 148 & 302 \\
\hline 22 & Abdominal depth, sitting & 245 & 50 & 171 & 505 \\
\hline 23 & Head breadth, sitting & 159 & 6 & 145 & 172 \\
\hline 24 & Biacromial shoulder breadth, sitting & 436 & 29 & 383 & 567 \\
\hline 25 & Bideltoid shoulder breadth, sitting & 494 & 47 & 366 & 690 \\
\hline 26 & Hip breadth, sitting & 384 & 39 & 316 & 531 \\
\hline 27 & Arm reach to wall, lateral, standing & 872 & 57 & 739 & 977 \\
\hline 28 & Shoulder-fist length, standing & 744 & 54 & 585 & 859 \\
\hline 29 & Maximum horizontal reach, standing & 1375 & 119 & 899 & 1923 \\
\hline 30 & Maximum vertical reach, standing & 1875 & 158 & 1417 & 2146 \\
\hline 31 & Maximum Arms Span, standing & 1759 & 84 & 1525 & 1940 \\
\hline 32 & Elbow-to-elbow breadth, standing & 902 & 47 & 794 & 1015 \\
\hline 33 & Hand length & 187 & 9 & 168 & 208 \\
\hline 34 & Hand breadth & 93 & 89 & 69 & 830 \\
\hline 35 & Foot length, standing & 263 & 14 & 231 & 295 \\
\hline 36 & Foot breadth, standing & 96 & 6 & 74 & 109 \\
\hline
\end{tabular}

S.D.: standard deviation; Min: minimum; Max: maximum; P: percentile. All dimensions in mm; body weight in kg. 
Table 3. Anthropometric data of female students.

\begin{tabular}{|c|c|c|c|c|c|}
\hline \multirow{2}{*}{$\mathrm{N}^{\circ}$} & \multirow{2}{*}{ Body dimension } & \multicolumn{4}{|c|}{ Female $(\mathrm{N}=70)$} \\
\hline & & Mean & S.D. & Min & Max \\
\hline 1 & Body weight & 59 & 13 & 39 & 110 \\
\hline 2 & Stature, standing & 1599 & 60 & 1478 & 1746 \\
\hline 3 & Eye height, standing & 1503 & 63 & 1380 & 1769 \\
\hline 4 & Shoulder height, standing & 1314 & 54 & 1190 & 1447 \\
\hline 5 & Elbow height, standing & 1015 & 45 & 931 & 1140 \\
\hline 6 & Hip height, standing & 929 & 49 & 810 & 1044 \\
\hline 7 & Knuckle height, standing & 712 & 34 & 654 & 812 \\
\hline 8 & Finger tips height, standing & 622 & 36 & 560 & 709 \\
\hline 9 & Height, sitting & 1251 & 44 & 1153 & 1392 \\
\hline 10 & Eye height, sitting & 1158 & 59 & 1058 & 1445 \\
\hline 11 & Shoulder height, sitting & 967 & 43 & 865 & 1075 \\
\hline 12 & Thigh height, sitting & 563 & 45 & 491 & 713 \\
\hline 13 & Knee height, sitting & 479 & 28 & 418 & 537 \\
\hline 14 & Popliteal height, sitting & 424 & 28 & 354 & 486 \\
\hline 15 & Thigh thickness, sitting & 131 & 20 & 100 & 202 \\
\hline 16 & Buttock-knee length, sitting & 562 & 31 & 501 & 647 \\
\hline 17 & Buttock-popliteal length, sitting & 466 & 29 & 408 & 537 \\
\hline 18 & Head length, sitting & 190 & 7 & 176 & 210 \\
\hline 19 & Shoulder-elbow length, sitting & 326 & 20 & 270 & 362 \\
\hline 20 & Elbow-finger tips length, sitting & 424 & 24 & 376 & 498 \\
\hline 21 & Thorax depth, sitting & 203 & 20 & 162 & 260 \\
\hline 22 & Abdominal depth, sitting & 204 & 33 & 154 & 303 \\
\hline 23 & Head breadth, sitting & 151 & 6 & 139 & 164 \\
\hline 24 & Biacromial shoulder breadth, sitting & 368 & 22 & 330 & 477 \\
\hline 25 & Bideltoid shoulder breadth, sitting & 417 & 37 & 305 & 495 \\
\hline 26 & Hip breadth, sitting & 382 & 43 & 195 & 481 \\
\hline 27 & Arm reach to wall, lateral, standing & 777 & 52 & 659 & 883 \\
\hline 28 & Shoulder-fist length, standing & 666 & 40 & 575 & 747 \\
\hline 29 & Maximum horizontal reach, standing & 1331 & 124 & 1160 & 1766 \\
\hline 30 & Maximum vertical reach, standing & 1730 & 187 & 1228 & 2015 \\
\hline 31 & Maximum Arms Span, standing & 1590 & 80 & 1342 & 1763 \\
\hline 32 & Elbow-to-elbow breadth, standing & 809 & 58 & 528 & 930 \\
\hline 33 & Hand length & 169 & 9 & 155 & 190 \\
\hline 34 & Hand breadth & 74 & 3 & 65 & 84 \\
\hline 35 & Foot length, standing & 235 & 12 & 212 & 258 \\
\hline 36 & Foot breadth, standing & 87 & 6 & 77 & 105 \\
\hline
\end{tabular}

S.D.: standard deviation; Min: minimum; Max: maximum; P: percentile. All dimensions in mm; body weight in kg. 


\subsection{Data Comparison with Other Samples from Mexico}

Body weight and stature dimensions obtained in this study were compared to data gathered from Ciudad Juarez [9] and three regions of Mexico [6] (Guadalajara, León, and Mexico City). Information includes anthropometric data of students, workers, and drivers. Figure 1 shows the results of the body weight comparisons of male and female subjects.

Body weight of male students from Ciudad Juarez was significantly higher than the other five Mexican regions $(t=3.070, p=0.003)$. Body weight of female students was significantly lower than workers of Guadalajara [6] $(t=-2.088, p=0.042)$, had no significant differences with female workers of Ciudad Juarez [9] $(t=-0.973, p=0.335$ ), and Mx-USA border [6] $(t=0.700, \mathrm{p}=0.487)$, and was significantly higher than students of Guadalajara $(t=2.930, p=0.005)$. The stature of male students from Ciudad Juarez had no significant differences with male workers of Ciudad Juarez [9] ( $t=-0.277$, $p=0.782)$ and was significantly higher than the other four Mexican regions $(t=2.802$, $p=0.006$ ). The stature of female students had no significant differences with female workers of Ciudad Juarez [9] $(t=-0.806, p=0.424)$ and was significantly higher than the other four Mexican regions $(t=3.447, p=0.001)$.

\subsection{Predictive Models for the Dimensions of Body Segments}

Considering the large amounts of work, time, and resources invested in the conduction Body weight
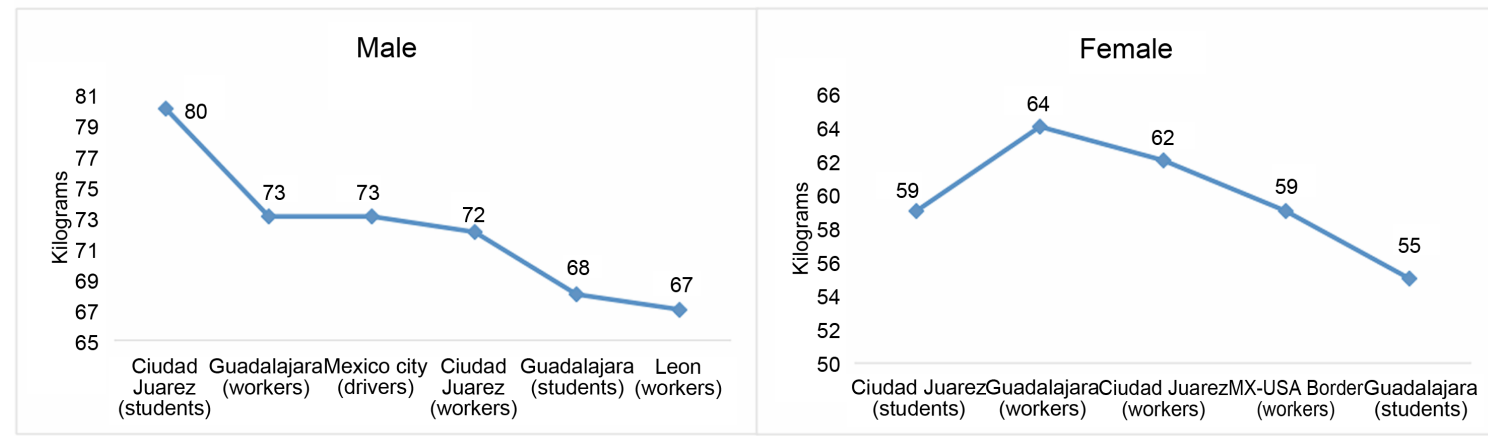

Stature
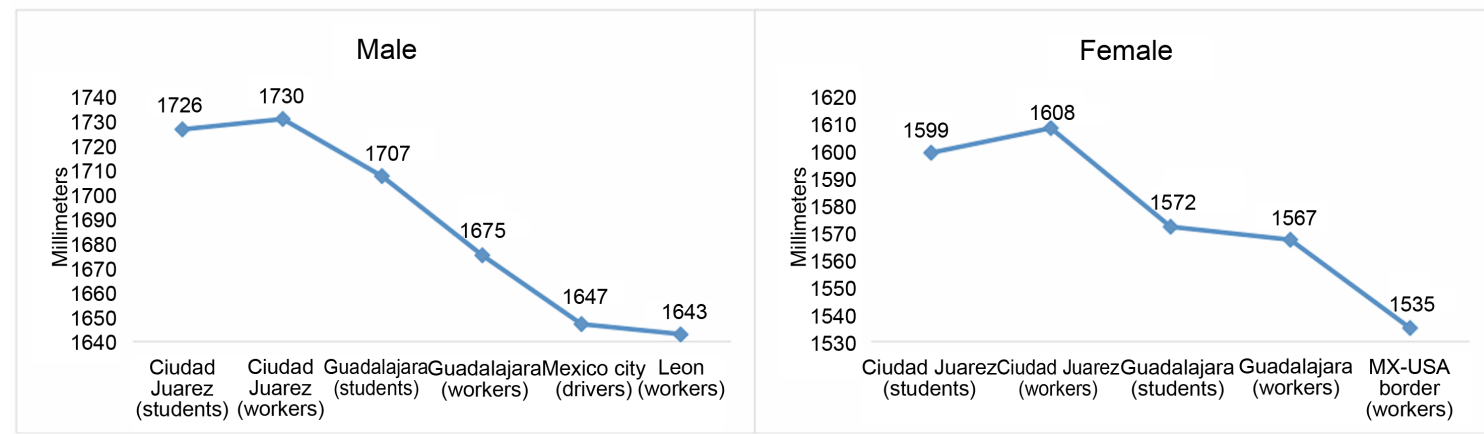

Figure 1. Body weight and Stature comparison between students of Ciudad Juarez and people of other Mexican regions. 
of an anthropometric study, it is desirable to develop linear regression models with which to predict the dimensions of some body segments, based on the value of another salient anthropometric feature. Stature is the logic candidate for this role, mainly due to two factors: 1) it is by far the easiest dimension to be measured and 2) a large number of body dimensions show high levels of correlation with it.

Predictive models are useful when a design for a specific user is required, or when a rapid prototype to be used by individuals with similar anthropometric characteristics is needed. Foot-breadth and foot-length dimensions obtained a significant predictive model; however, they were not included in the list. Table 4 shows the 26 significant predictive models (including male and female results) generated through linear regression analysis.

In order to exemplify the use of the predictive models, an example related with the design of a chair for a single male user with a stature of $1700 \mathrm{~mm}(\mathrm{X})$. In this case, it was necessary to determine the Seat Height $(\mathrm{SH})$ and the Seat Deep (SD) of the chair. Using the model 12 (see Table 4), the prediction of $\mathrm{SH}$ was $418.64 \mathrm{~mm}$ (see Equation (2)). Using the model 14 (see Table 4), the prediction of the SD was $471.73 \mathrm{~mm}$ (see Equation (3)).

$$
\begin{aligned}
& \mathrm{SH}=0.272(\mathrm{X})-10.851=0.272 * 1700 \mathrm{~mm}-10.85=418.64 \mathrm{~mm} \\
& \mathrm{SD}=0.32(\mathrm{X})-72.268=0.32 * 1700 \mathrm{~mm}-72.268=471.73 \mathrm{~mm}
\end{aligned}
$$

\section{Discussion}

Data of thirty-six body dimensions of 140 students (70 men and 70 women) from the north of Mexico were collected and analyzed. Due to the average body weight of male students was at least $7 \mathrm{~kg}$ more than the body weight of the other male subjects included in this study, it was significantly higher than the body weight of the people of the five regions of Mexico considered in this study, even more than $13 \mathrm{~kg}$ than workers of the Leon city. Contrary to the body weight of male students, the body weight of female students had no significant differences with female workers of Ciudad Juarez and Mx-USA Border. The stature of male and female students and male and female workers of Ciudad Juarez had no significant differences. These results indicate that geographic origin, despite the same country, does have a significant effect on variation of anthropometric dimensions [18], mainly in body weight and stature.

An important issue that affects the stature and weight of every population is the age [19]; however, this variable was not considered in the comparisons developed in this study. In this context, students of Ciudad Juarez and Guadalajara had similar age. In contrast, the workers of Ciudad Juarez, Guadalajara, and Leon and drivers of Mexico City were older than the students of Ciudad Juarez.

Anthropometric data gathered in this study is useful in the design of products for the Industrial Design students. Using the mean and standard deviation, calculation of percentiles only needs an easy step. Although the participants' sample was limited, anthropometric data could be useful to design processes, products, furniture, tools, among 
Table 4. Predictive models of body segments.

\begin{tabular}{|c|c|c|c|}
\hline Body dimension & Gender & R-value & Predictive model \\
\hline \multirow{2}{*}{$\mathrm{Y}_{1}$. Eye height, standing } & M & 0.987 & $Y=0.867(X)+121.28$ \\
\hline & $\mathrm{F}$ & 0.885 & $Y=0.937(X)+5.095$ \\
\hline \multirow{2}{*}{$\mathrm{Y}_{2}$. Shoulder height, standing } & M & 0.950 & $Y=0.870(X)-75.450$ \\
\hline & $\mathrm{F}$ & 0.983 & $Y=0.852(X)-48.861$ \\
\hline \multirow{2}{*}{$\mathrm{Y}_{3}$. Elbow height, standing } & M & 0.618 & $Y=0.553(X)+145.45$ \\
\hline & $\mathrm{F}$ & 0.887 & $Y=0.661(X)-42.431$ \\
\hline \multirow{2}{*}{$\mathrm{Y}_{4}$. Hip height, standing } & M & 0.787 & $Y=0.683(X)-184.23$ \\
\hline & $\mathrm{F}$ & 0.886 & $Y=0.719(X)-220.49$ \\
\hline \multirow{2}{*}{$\mathrm{Y}_{5}$. Knuckles height, standing } & M & 0.824 & $Y=0.483(X)-74.490$ \\
\hline & $\mathrm{F}$ & 0.743 & $Y=0.424(X)+34.197$ \\
\hline \multirow{2}{*}{$\mathrm{Y}_{6}$. Fingertips height, standing } & M & 0.800 & $Y=0.439(X)-95.132$ \\
\hline & $\mathrm{F}$ & 0.663 & $Y=0.388(X)-15.284$ \\
\hline \multirow{2}{*}{$Y_{7}$. Height, sitting } & M & 0.832 & $Y=0.583(X)+302.98$ \\
\hline & $\mathrm{F}$ & 0.769 & $Y=0.564(X)+384.921$ \\
\hline \multirow{2}{*}{$\mathrm{Y}_{8}$. Eye height, sitting } & M & 0.764 & $Y=0.484(X)+374.82$ \\
\hline & $\mathrm{F}$ & 0.535 & $Y=0.523(X)+320.962$ \\
\hline \multirow{2}{*}{$\mathrm{Y}_{9}$. Shoulder height, sitting } & M & 0.694 & $Y=0.400(X)+317.25$ \\
\hline & $\mathrm{F}$ & 0.714 & $Y=0.507(X)+156.25$ \\
\hline \multirow{2}{*}{$\mathrm{Y}_{10}$. Thighs height, sitting } & M & 0.664 & $Y=0.371(X)-117.49$ \\
\hline & $\mathrm{F}$ & 0.535 & $Y=0.406(X)-86.56$ \\
\hline \multirow{2}{*}{$\mathrm{Y}_{11}$. Knee height, sitting } & M & 0.797 & $Y=0.183(X)-117.497$ \\
\hline & $\mathrm{F}$ & 0.723 & $Y=0.332(X)-52.076$ \\
\hline \multirow{2}{*}{$\mathrm{Y}_{12}$. Popliteal height, sitting } & M & 0.462 & $Y=0.183(X)+107.54$ \\
\hline & $\mathrm{F}$ & 0.579 & $Y=0.272(X)-10.851$ \\
\hline \multirow{2}{*}{$\mathrm{Y}_{13}$. Buttock-knee length, sitting } & M & 0.776 & $Y=0.374(X)-43.011$ \\
\hline & $\mathrm{F}$ & 0.798 & $Y=0.409(X)-92.82$ \\
\hline \multirow{2}{*}{$\mathrm{Y}_{14}$. Buttock-popliteal cavity length, sitting } & M & 0.639 & $Y=0.320(X)-72.268$ \\
\hline & $\mathrm{F}$ & 0.582 & $Y=0.277(X)+22.88$ \\
\hline \multirow{2}{*}{$\mathrm{Y}_{15}$. Shoulder to elbow length, sitting } & M & 0.499 & $Y=0.182(X)+35.841$ \\
\hline & $\mathrm{F}$ & 0.779 & $Y=0.260(X)-89.97$ \\
\hline \multirow{2}{*}{$\mathrm{Y}_{16}$. Elbow to fingertip length } & M & 0.832 & $Y=0.280(X)-4.750$ \\
\hline & $\mathrm{F}$ & 0.842 & $Y=0.338(X)-117.29$ \\
\hline \multirow{2}{*}{$\mathrm{Y}_{17}$. Thigh Thickness, sitting } & M & 0.341 & $Y=0.94(X)-20.526$ \\
\hline & $\mathrm{F}$ & 0.328 & $Y=111(X)-46.619$ \\
\hline \multirow{2}{*}{$\mathrm{Y}_{18}$. Briacromial shoulder breadth, sitting } & M & 0.457 & $Y=186(X)+115.026$ \\
\hline & $\mathrm{F}$ & 0.492 & $Y=178(X)+83.68$ \\
\hline \multirow{2}{*}{$\mathrm{Y}_{19}$. Bideltoid shoulder breadth, sitting } & M & 0.279 & $Y=184(X)+176.71$ \\
\hline & $\mathrm{F}$ & & NS \\
\hline \multirow{2}{*}{$\mathrm{Y}_{20}$. Arm Reach to wall lateral, sitting } & M & 0.678 & $Y=538(X)-56.43$ \\
\hline & $\mathrm{F}$ & 0.568 & $Y=0.494(X)-11.937$ \\
\hline \multirow{2}{*}{$\mathrm{Y}_{21}$. Shoulder fist length, standing } & M & 0.614 & $Y=0.461(X)-51.38$ \\
\hline & $\mathrm{F}$ & 0.611 & $Y=0.412(X)+7.504$ \\
\hline & M & 0.404 & $Y=0.673(X)+213.58$ \\
\hline $\mathrm{Y}_{22}$. Maxımum horızontal reach, standıng & $\mathrm{F}$ & 0.400 & $Y=0.828(X)+7.336$ \\
\hline Y Maximum verticl reach standino & M & 0.449 & $Y=1.103(X)-28.15$ \\
\hline$Y_{23}$. Maximum vertical reach standing & $\mathrm{F}$ & 0.370 & $Y=1.151(X)-111.47$ \\
\hline Y Maximum arms snan standing & M & 0.840 & $Y=0.988(X)+53.94$ \\
\hline $\mathrm{Y}_{24} \cdot$ Maximum arms span, standing & $\mathrm{F}$ & 0.766 & $Y=1.028(X)-54.78$ \\
\hline Y Elbow to elbow breadth standing & M & 0.774 & $Y=0.512(X)+17.40$ \\
\hline$Y_{25}$. Elbow to eldow breadth, standing & $\mathrm{F}$ & 0.655 & $Y=0.629(X)-197.30$ \\
\hline & M & 0.681 & $Y=0.087(X)+36.253$ \\
\hline $\mathrm{Y}_{26}$. Hand length & $\mathrm{F}$ & 0.758 & $Y=0.111(X)-9.086$ \\
\hline
\end{tabular}


others for the working population of the Ciudad Juarez and nearby cities. Additionally, data could be useful for research purposes.

The linear regression analysis showed that dimensions of 26 body segments positively correlated with the stature. Nonetheless, although all the predictive models were statistically significant, only three dimensions (eye height standing, shoulder height standing, and elbow to fingertip length sitting) yielded regression coefficients higher than 0.8 , which means that the level of correlation is very good [20] and the prediction based on those three linear regression models will be reasonably reliable. However, for popliteal height sitting, thickness sitting, biacromial shoulder breadth sitting, bideltoid shoulder breadth sitting, maximum horizontal reach standing, and maximum vertical reach standing yielded correlation coefficients between 0.2 and 0.5 considered as low/bad [20]. Thus, the length estimation of these body segments will produce a gross error, being highly unreliable.

\section{Conclusions}

The data presented in this article comes from a small sample of university students in northern Mexico and does not represent the country's entire population. The average values of the dimensions stature and weight (of students of Ciudad Juarez) for our subjects were higher than those measured on people from other three regions in Mexico.

Using linear regression procedures, 26 predictive models of body segments based on the stature were generated and could be used to develop rapid prototypes and product design for specific users. However, these models are reasonably reliable only for the dimensions eye height standing, shoulder height standing, and elbow to finger-tip length sitting.

With this study, we now hold anthropometric data of 36 body dimensions that could be used in the design of models, prototypes, and products by Industrial Design students. The most important limitations of this study were the low number of participants and their origins (university students). Therefore, these two factors should be considered when using the data to design objects/products for different populations.

\section{Acknowledgements}

This research was supported by the Design Department of the Universidad Autonoma de Ciudad Juarez with the purchase of the anthropometry kits and the preparation of the Ergonomic Product Design Lab where the study was conducted. In the same way, the authors thank the staff at the Ergonomics Lab of the Universidad de Guanajuato for their support during the study.

\section{References}

[1] Gouvali, M.K. and Boudolos, K. (2006) Match between School Furniture Dimensions and Children's Anthropometry. Applied Ergonomics, 37, 765-773.

https://doi.org/10.1016/j.apergo.2005.11.009

[2] León, N. (1933) La antropología física y la antropometría en México, notas históricas. 
Anales Del Museo Nacional de Arqueología, Historia Y Etnografía, 1 (Cuarta época), 99-136.

[3] Casillas, L.E., Vargas-Guadarrama, L.A. and Martínez-Malo, L.M. (1978) Antropometría de estudiantes y trabajadores universitarios: comunicación preliminar. Anales de Antropología, 15, 293-309.

[4] Bonilla, E. (1993) La técnica antropométrica aplicada al diseño industrial. First Edition, Universidad Autonoma Metropolitana, Mexico City.

[5] SEMAC (2015) Sociedad de Ergonomistas de México, 1-2. www.semac.org.mx

[6] Ávila-Chaurand, R., Prado-León, L.R. and González-Muñoz, E.L. (2007) Dimensiones antropométricas de población latinoamericana. Universidad de Guadalajara, Guadalajara City.

[7] Prado-León, L.R., Avila-Chaurand, R. and González-Muñoz, E.L. (2001) Anthropometric Study of Mexican Primary School Children. Applied Ergonomics, 32, 339-345. https://doi.org/10.1016/S0003-6870(01)00009-6

[8] De la Vega Bustillos, J.E., López-Millan, F.O. and Soto, S. (2004) Antropometría para discapacitados. Sociedad de Ergonomistas de México, 1, 236-248.

[9] Ibarra Mejia, G., Fernandez, J.E., Ware, B., Mital, A., Gomez-Bull, K.G. and Salinas, I.N. (2010) Sitting and Standing Dynamic Anthropometric Measures in a Sample of Mexican Manual Assembly Workers. Proceedings of the 15th Annual International Conference on Industrial Engineering Theory, Applications and Practice, Mexico City, 512-518.

[10] de la Vega Bustillos, J.E., Duarte, K.L. and Millán, O.L. (2010) Mexican Practical Anthropometry of Automotive Industry Workers. Proceedings of the Human Factors and Ergonomics Society Annual Meeting, 54, 1125-1129. https://doi.org/10.1177/154193121005401507

[11] Aguilar-Duque, J.I., Salinas-Coronado, J., Sánchez-González, J.L. and Hernández-Arellano, J.L. (2014) Determinación de Dimensiones Antropométricas para el Desarrollo de Herramientas Manuales. Congreso Internacional de Investigación Academia Journals, 5, $38-42$.

[12] Velázquez-Alva, M.D.C., Castillo-Martínez, L., Irigoyen-Camacho, E., Zepeda-Zepeda, M.A., Gutiérrez-Robledo, L.M. and Cisneros-Moysen, P. (1996) Estudio antropométrico en un grupo de hombres y mujeres de la tercera edad en la Ciudad de México. Salud Pública de México, 38, 466-474.

[13] Padilla-Pérez, J., Taylor, A.W., Yuhasz, M.S. and Velázquez-Hernández, M.A. (2004) Algunas características antropométricas de una población de atletas mexicanos. Revista Médica Del Hospital General de México, 67, 11-21.

[14] Balderas-Bautista, R. (2006) Tablas antropométricas de adultos con enanismo de entre 18 a 45 años de edad para el diseño de mobiliario. Encuentro Universitario de Ergonomía, 1-9.

[15] Drillis, R., Contini, R. and Bluestein, M. (1964) Body Segment Parameters: A Survey of Measurement Techniques. Artificial Limbs, 25, 44-66.

[16] Pheasant, S. and Haslegrave, C.M. (2006) Bodyspace: Anthropometry, Ergonomics, and the Design of Work. CRC Press, Boca Raton.

[17] Hertzberg, H.T.E. (1968) The Conference on Standardization of Anthropometric Technique and Terminology. American Journal of Physical Anthropology, 28, 1-16. https://doi.org/10.1002/ajpa.1330280110

[18] Chuan, T.K., Hartono, M. and Kumar, N. (2010) Anthropometry of the Singaporean and Indonesian Populations. International Journal of Industrial Ergonomics, 40, 757-766. https://doi.org/10.1016/j.ergon.2010.05.001 
[19] Kroemer, K., Kroemer, H. and Kroemer-Elbert, K. (2001) Ergonomics: How to Design for Easy and Efficiency. Prentice Hall. Upper Sadle River, 28-29.

[20] Montgomery, D.C. and Runger, G.C. (2006) Applied Statistics and Probability for Engineers. John Wiley \& Sons, Honoken, 458-489.

Submit or recommend next manuscript to SCIRP and we will provide best service for you:

Accepting pre-submission inquiries through Email, Facebook, LinkedIn, Twitter, etc. A wide selection of journals (inclusive of 9 subjects, more than 200 journals)

Providing 24-hour high-quality service

User-friendly online submission system

Fair and swift peer-review system

Efficient typesetting and proofreading procedure

Display of the result of downloads and visits, as well as the number of cited articles

Maximum dissemination of your research work

Submit your manuscript at: http://papersubmission.scirp.org/

Or contact ojsst@scirp.org 